\title{
THE EFFECTS OF THE INTERNATIONAL CONTRACT FOR SALE OF GOODS
}

\author{
Associated Professor Daniel Berlingher, PhD \\ "Vasile Goldiș" Western University of Arad, Faculty of Law \\ E-mail: daniel.berlingher@uvvg.ro
}

(Received May 2017; Accepted June 2017)

\begin{abstract}
The contracts are the indispensable legal instruments for any economic transaction. The international sale contract is the main legal instrument by which international commerce is carried out and through which the movement of goods from producer to consumer is ensured within cross-border relations. The sale contract in international commerce is the legal act by which the parties, the seller and the buyer, belonging to different states, commit each other to transfer the property of a good in return for payment of a price. Regarding the general rules applicable to the contract of international sale of goods, they are regulated by the "United Nations Convention on Contracts for the International Sale of Goods from Vienna". The Convention has adopted uniform rules to govern the international sale of goods contract, if the parties have not chosen expressly for the application of other rules. In this study I present the effects of international sale of goods in the light of the rules of the Vienna Convention of 1980.
\end{abstract}

\section{General considerations}

The United Nations Convention on contracts for the international sale of goods is a summary of the most important law systems, in the field of international merchandising, i.e. mostly between the Romanist (Roman-Germanic) system and the Anglo-Saxon one (of common law), which ensured the success and the relatively wide success and adherence to the Convention. Key tool in levelling the international trade law, the Vienna Convention adopts modern solutions, compatible with the current requirements of the international trade relations. [1]

At international level, the Convention became effective on January 1, 1988, and over 85 States have ratified it currently, turning it into one of the most successful uniform international laws.

The Convention has four parts: the scope and general provisions (First Part), Forming the agreement (Second part), Sale of Goods (Third Part) and Final provisions (Fourth Part). According to the provisions of the art. 92, upon becoming a member of the Convention, any State may declare not the it is not bind by Second or Third Part of the Convention.

The goal of the Vienna Convention was to set a complex of uniform material legal norms enforceable to the international sales agreements and aimed for the use of the signatory states without appealing to own national regulations on the matter. [2] 
Attached to the need for legislation alignment to international tendencies, Romania proved receptive to the motivation of the juridical rigor, ratifying the Vienna Convention on the international sale of goods agreement (1980) by Law no. 24/1991 [3], and the Convention on the prescription in the matter of international sale of goods (1974) by Law no. 24/1992 [4]. The provisions of the Vienna Convention of 1980 became effective starting June 1, 1992, Romania expressed no reserve or statement so the adhesion was for the entire convention.

\section{The contract for sale in international trade}

\section{a. Notion}

The contract for sale in international trade is the legal document where the parties, seller and buyer, belonging to different States, undertake mutually to transfer the property of a good against the payment of a price.

\section{b. Juridical character}

The juridical characters may be divided into two categories if they coincide with those of the common law or if they are specific. [5]

\section{b.1. Common characteristics}

- it is a synallagmatique, bilateral contract, producing mutual obligations for both parties.

- it is a contract with onerous title, the parties aiming for patrimonial interests.

- the sale contract is a commutative agreement, extending the parties rights and obligations being known in the moment of concluding the act of will.

\section{b.2. Specific or particular characteristics}

- the sales contract has a commercial character, regulating only the relations occurring in the operations of foreign trade.

However, at international level, the difference between the commercial sale and the civil one has a minor signification. The regulations on the matter do not provide for any distinction, as both sales are subject to identical norms.

- the sales contract has an international character as it includes elements of extraneity.

\section{c. The object of the contract}

In the international trade, the object of the sales contract is the sold merchandise, in exchange for which the buyer pays the agreed price to the seller.

In the international trade practice, when establishing the object of the contract, a distinction is made in what concerns the nature of goods, meaning:

- for fungible goods, the object is set by quality parameters and general quantity. The buyer indicates the specifications for each delivery in the orders. 
- at non-fungible goods, the object is set by precise and detailed elements.

\section{The effects of the sales contract}

In the international trade, the effects of the sale-purchase agreement concretise into the obligations resulting in the parties' tasks and in the transmission of ownership and of the risks.

\section{a. Transmission of the ownership and of the risk}

In Romanian law, the transmission of the ownership of the goods to the buyer occurs just by the effect of the agreement conclusion. Nevertheless, the rule, stipulated in art. 1674 of the Romanian Civil Law is elective, the parties having the option to derogate from its provisions.

There is no unitary regulation on this in the other law systems. However, the diversity of the solutions may be grouped in the following two ways:

- the ownership is transmitted when concluding the agreement of will;

- the ownership transmissions occur when delivering the sold goods.

The work risk is transmitted with the ownership transfer. According to the applicable regulations, the risk is to be borne by the buyer either upon the conclusion of the agreement, or in the moment of the work tradition.

In the practice of the international trade, the parties determine the risk transmission by including the standard clauses in the agreement. In principle, there is for each way of sales a certain time for the risks transfer.

According to the uniform law on the international sale of mobile corporal goods, the risks are deferred to the buyer even in the situation of the delivery of inadequate merchandise if the agreement resolution or the work replacement has not been requested. In the situation where the delivery is delayed by buyer's fault, the risks have to be transmitted since the time when the merchandise delivery should have occurred, as stipulated in the agreement.

There is no mandatory correlation between the two transfers. The risk and the ownership may be regarded also as independent times.

Moreover, the parties may stipulate in the agreement other times for risks transfer. Under such circumstances, the parties' intentions must occur clearly and precisely.

In the absence of an express clause, the risks transfer is submitted to the applicable law of the agreement, lex contractus, (in this regard, the Vienna Convention, 1980).

\section{b. Obligations of the seller (art. 30 of the Vienna Convention, 1980)}

In the sales agreement in international trade, the seller has an important and active position. Seller's role concretises especially into the following obligations:

- effective delivery of the sold goods; 
- provision of the compliance of the delivered goods with the agreement clauses; - delivery of the technical documentation.

\section{Delivery of the sold goods}

In international trade, the delivery consists of the documents, the facts or the proceedings to remitting the goods to the buyer.

\section{$i$. Delivery deadline}

For the seller, the delivery of the goods implies the compliance with the time of execution of the obligation. In international trade, there is the principle that the partners agree to sell and to buy only within a certain timeframe.

The setting of the deadline depends on the object of the agreement being of fungible or non-fungible goods. [6]

Related to the possibility of existence of some additional data, the deadline may be rigorous or firm and simple.

According to the deadline type, the delivery may be:

- prompt, when the goods are shipped within 15 days since the setting of the agreement;

- upon term, when the agreement stipulates precisely the delivery date;

- as soon as it is ready or immediately after being possible, without being more of 45 days since the setting of the agreement.

The contracting parties or the commercial usage may set the deadline. If the goods are to be shipped during a certain time and if there is no other provision, the seller may establish the exact date of the delivery.

The parties may opt for any way of setting the deadline.

In the absence of some clauses or indications, the delivery is carried on within a reasonable timeframe, depending on the nature of the goods and of the agreement circumstances.

In the international trade practice, the delivery deadlines are calculated since the time of conclusion of the agreement. If the delivery obligation is conditioned by a fact done by the buyer, the deadline starts to be in force after the achievement of the above.

The delivery of the goods before the established deadline or the partial delivery can be performed only upon the prior approval from the buyer. By complying with this term, the anticipated delivery is considering a delivery on time.

If the seller does not accomplish in time the obligation of goods delivery, it is not required the remittal in delay. The principle dies interpellat pro homine (i.e. anyone who undertakes the delivery of a labour conscription has to fulfil it under the sanction of payment of damages or the deadline fulfilment operates by itself the debtor's remittal in delay without being required for the creditor to act in this regard) operates in the trade relations, unlike the common law. 


\section{ii. Place of delivery}

The seller delivers the goods at the location agreed in the agreement. Usually, the delivery location is related to the delivery requirement stipulated by the parties.

In international practice, the following situations can be noticed when establishing the delivery place:

- when the goods shipment is not stipulated in the agreement, the place of delivery is at the seller's domicile. The individualisation of the domicile is made in relation with the time of concluding the agreement.

- if the merchandise needs to be shipped, the place of delivery is where the goods are delivered to the carrier. In addition, when the goods are found or they are going to be manufactured in a certain locality, known by the parties upon the conclusion of the agreement, the delivery place is where the goods are.

\section{iii. Liability for not performing the delivery obligation}

The seller may not perform the obligation to deliver the merchandise on the agreed time and place, this situation conferring the buyer with the following possibilities:

- to ask for the further execution of the agreement;

- to declare the agreement resolution.

In the first hypothesis, for the further execution of the agreement, the buyer may claim for delay penalties.

The buyer may also provide the seller with an additional delivery deadline. If the seller does not comply with the given deadline as well, the buyer has the right to renounce to execute the agreement - art. 46 - 52 of the Vienna Convention, 1980. For the second hypothesis, the buyer may ask for the agreement resolution, which presents the following features:

- the jurisdictional bodies may not grant grace periods;

- the party opting for the resolution may not ask for the execution of the agreement; -after the introduction of the action in resolution, the debtor may fulfil its obligations only for the agreements without deadline;

-the resolution may be both judicial and of law.

The uniform Law on the international sale of mobile corporal goods provides for an interesting regulation in this matter, specifically:

- if the non-performance of the seller's obligation for delivery is an essential breach of the agreement, the buyer has the right for option between execution and resolution. It is required that the choice is made within a reasonable timeframe. Otherwise, the agreement is cancelled by law.

- when the non-fulfilment of the obligation is a non-essential breach of the agreement, the seller may further execute the delivery. In addition, the purchaser is entitled to ask for the execution and to provide with a supplementary deadline. 
- thus, the effects of non-delivering the goods are configured by the character of the agreement violation: essential or non-essential. According to art. 10 of the uniform law, a breach of the agreement is essential when the failing party was aware or has to be aware of the fact that the other party might not have been concluded the agreement if this breach and its effects would have been stipulated.

- the buyer may ask for damages for the losses caused by the non-performance of the delivery obligation. The damages are paid only for the effective occurred prejudice.

\section{iv. The exoneration of liability}

The seller is exonerated of liability if the non-performance of the delivery obligation is due to major force.

The major force is an unpredictable and insurmountable event, occurred after the conclusion of the agreement, independent of parties' will and which renders impossible the performance of the obligations.

There are several types of major force definitions used in the international practice. They have synthetic, analytic or mixed character (art 79 par. 3 of the Vienna Convention, 1980).

The circumstances of major force causing the delay in performance are to be notified in writing to the other party, within a certain time delay. The general delivery terms and the standard agreements stipulate that the notification has to be communicated without delay and within the limits of the deadline for achieving the contract obligations, as soon as the event occurs, in due time or within 15 days .

The circumstance of major force may cause the impossibility of total or partial execution. Implicitly, the exoneration of liability is to be proportional with the occurred consequences.

\section{Compliance of the delivered goods}

The seller has to deliver the sold goods to the buyer. In the same time, the delivered goods have to be compliant with the agreement clauses, without flaws or vices.

It is understood by compliance that the delivered goods possess the explicitly or tacitly qualities or particularities stipulated in the agreement.

The compliance is established considering the agreement provisions on the goods quantity and quality. The time of assessing the compliance is that of the risk transmittal (art 36 of the Vienna Convention, 1980).

The goods delivered must be the following conditions relating to:

- Quantity of goods

The quantity is established considering the nature of the goods and the customs, by employing specific measure units. 
The quantity may be established at the sending or destination locations. Sometimes, a double determination can be used, the quantity being checked both at shipment and on destination.

According to international customs, the quantity of the delivered goods is certified by the following documents:

- letter of international carriage, for the railway and air transports;

- bill of landing, for the maritime transports;

- transport document, for the shipment by vehicles;

- post receipt, for the post transport.

- Quality of the goods

The quality is the totality of the features which the goods has, manufactured at the level of the modern technology and because of which it is preferred, complying, in optimal conditions, with the buyer's needs.

The quality refers to the following aspects:

- technical characteristics of the goods;

- functionality of the goods;

- the degree of the goods correspondence with the requirements for which it has been manufactured.

\section{- Establishing the quality of the goods}

According to these criteria, the quality of the goods in the sales-purchase agreement can be established by several methods in the practice of the international trade. A certain number of elements is used, such as [7]:

\section{- Seen and liked.}

For the method 'seen and liked', the buyer checks the goods and agrees with its quality. The agreement is concluded without requiring a technical description.

\section{- After testing.}

In this option, the goods are submitted to certain trials. The conclusion of the agreement is affected by the term of the buyer's acceptance of the goods quality.

- Tasting or tasting samples.

For some food, the quality is established by tasting the parts. The selling by tasting is still a sub-requirement.

\section{- Tel quel or tale quale.}

By the tale quale clause, the buyer agrees to receive the goods as they are. The acceptance can occur regardless of the verification of the goods.

Juridically, the tale quale clause is likely to the sale-purchase action in the option after trials.

$$
\text { - Rye Terms (R.T.) }
$$


According to Rye-Terms clause, the buyer is to receive the goods in the state in which they are upon arrival. However, a bonification could be asked for, if the state of the goods is not appropriate.

-Sound Delivered (S.D.)

Likely to the Rye Terms, the Sound Delivered clause allows for the buyer to deny the damaged goods. The denial causes effects only if the seller is notified within the agreement stipulated deadline.

- Samples, models, benchmarks

The sample is a representative part, of small sizes, without usual usage or a complete item of the goods which is subject to the agreement.

According to the party providing it, the sample may be for tender, having also the function of information or order. The partners may also use the probe sample, which is extracted from the lot of goods to be delivered.

In case of conclusion of the agreement, the respective sample is contractual or of reference, being a probe in establishing the quality. In such purpose, the referential sample is usually submitted to a third. The goods to be delivered by the seller have to have the same qualities with the sample. The buyer may repeal the quality of the goods, the compliance being established by expertise. If the delivered goods do not correspond to the sample, the buyer is entitled to damages or discounts.

\section{- Usual types and names.}

The type represents an abstract notion to which the quality of the goods to be delivered must correspond or be as close as possible.

The types are mostly used in the trade with agricultural products and ore. Thus, there is the f.a.g. quality (fair average quality) in the trade of cereals.

The quality of the goods may also be established by specifying some known or usual nominatives. In this regard, the lemons of Catania, the Chianti wine or the Singapore pepper are known.

- Norms and standards.

As options of the type of goods, the norms and standards are characteristics of the product which have been coded.

Internationally, the International Standardisation Organisation (I.S.O.) deals with the standardisation issues. A unification of the goods typology is achieved by using the ISO standards.

The standards in our country have the initials STAS. They are followed by the standard number.

- Description.

The establishment of the quality based on description is made by specifying in detail the technical characteristics of the goods. The origin of the goods, the manufacturing method, the physical or chemical properties may be specified. 
In the situation when the parties did not stipulate that the products must correspond to a certain quality, the seller has to deliver goods of usual average quality existing in its country and adequate for the destination stipulated in the agreement (art. 35 of the Vienna Convention, 1980).

\section{- Goods quality check}

The quality check can be performed by the seller at the location of goods shipment and on its expense. After performing the checking, the results must be certified by the buyer.

The quality check can be performed by the buyer at the shipment location or at the goods destination location. (art. 38 of the Vienna Convention, 1980)

In the situation where the buyer participates in the checking at the shipment location, either personally or by representative, it has to be notified in due time that the goods are ready for delivery. In the buyer's absence, the seller is entitled to perform self-reception.

\section{- The warranty of the goods quality}

The warranty of the good quality is the seller's obligation to keep the delivered product under the same quality terms for a specific timeframe.

By inserting the warranty clause, the seller is liable for the apparent and hidden flaws of the goods, being compelled to rectify any defection. In addition, the buyer has to provide for the normal use of the goods, according to its destination.

Related to the goods specificity, the warranty periods are established by the parties or result from the international practice. In principle, the provided periods for complex installations are high.

As for the warranty on the goods quality, the parties stipulate the following in the agreement:

- duration of the warranty;

- the date of the beginning of the warranty;

- what relates to the warranty;

- parties' liabilities.

\section{- Sanction of the lack of compliance}

If the delivered goods do not correspond to the agreement provisions, the buyer may denounce the lack of compliance by submitting a claim. It is intended to find an amiable solution and to avoid a dispute by the claim (art 74-77 of the Vienna Convention, 1980).

The denunciation is carried on shortly, usually within 30 days since the time when the buyer knew or had to know the lack of compliance. According to trading 
customs, the delay of claim submission on the quality is longer than the one for the quantity.

In the circumstances where the claim is not submitted within the stipulated delay, the buyer loses this right. In the same time, the buyer is deprived of the possibility to appeal to arbitrage or to the court.

The claim is submitted in writing. It can be sent by registered mail, telegram or telex.

Basically, the buyer must mention in the claim the following items:

- goods title;

- quantity for which the claim is issued;

- number of the agreement;

- data to allow for the goods identification;

- reason of the claim;

- buyer's demand.

The seller has to confirm the claim. The confirmation is in writing, within a certain delay.

After analysing the basic requirements of the claim, the seller has to inform on the way to solve it. The buyer must be notified on the decision within the agreed deadline stipulated in the agreement or immediately. By parties' convention, the delay for the reply may be extended.

If the denunciation of the lack of compliance occurs in consistency with all the terms, the buyer may claim for:

- further execution of the agreement;

- termination of the agreement;

- price reduction;

- payment with penalties.

As for the further execution of the agreement, when the seller accepts the buyers' demands, the claim may be solved as follows:

- removal of the deficiencies noticed upon destination by reconditioning the goods;

- restitution of the goods in order to be replaced;

- granting a bonification.

\section{Delivery of the technical documentation}

For the agreements on complete installations, large industrial objective, machinery or equipment, the seller must deliver the appropriate technical documentation and know-how. Thus, it is so provided their mounting, putting into function, maintenance and the possibility of a normal use (art. 34 of the Vienna Convention, 1980).

The technical documentation is submitted at the time and moment established by the parties or according to customs. 


\section{c. Buyer's obligations}

The buyer has two main obligations in the sales-purchase agreement (art. 53 of the Vienna Convention, 1980), namely:

- payment of the price;

- reception of the sold goods.

\section{Payment of the price}

The payment of the price is the buyer's undertaken obligation performed in the exchange of the received goods. The selling price comprises the internal cost to which several elements are added depending on the case.

\section{a.1. Establishing the price}

As general rule, the price is set on the characteristic market where the largest volume of export or import operations for the respective good is carried on. The setting of the price relies on an international average value.

The price can be determined or definable in the sales-purchase agreement.

The determined price is stipulated by the parties upon the conclusion of the agreement. It is registered by a fix or variable formula.

In the fix option, the parties set a unitary price for the product quantity. In addition, the price can also be contractual or global for the entire quantity of contracted goods.

The parties may also set a basic price. The effective price is to be established upon delivery, within the admitted margins and indicated proportions.

The definable price materialises after the conclusion of the agreement, considering some criteria. The parties may establish that the price setting is made according to the stock market quotations, to the average price of the quotations during the last 15 days prior to the delivery, to the average quotations on various markets or to the price on the date of delivery.

For the gradual deliveries on a longer timeframe, there is also stipulated a fluctuation of the worldwide prices, a mobile or sliding scale of prices can also be set. For the deliveries with a large cycle of production, there are also to be taken into consideration the fluctuations of the prices for the materials to be used in obtaining the product.

Furthermore, the parties may also prevent the consequences of the prices lowering or increasing. By inserting the provision of fall-risk-clause or hausse-baisseclause, the contractual price is to change depending on the market situation.

When establishing the price, the following items are also to be considered:

- the quantity which the price is calculated for;

- currency for the payment; 
- discounts granted to the buyer.

The price is in the currency of one of the countries or in a third currency, and the payment is in the reference currency or eventually in another one, stipulated by the parties. Usually, strong currency with full conversion rate is used.

\section{a.2. Elements of the price}

- packaging costs

For the goods shipment, the parties use a various and diverse range of packaging materials, regulated by the INCOTERMS Rules in 1990.

It is required in the sales-purchase agreement that the parties provide for the following items regarding the packaging:

- passing the packing into buyer's ownership;

- the seller renting the packaging and the way of returning it;

- price to be paid for the packaging.

As for the packaging costs, they depend on the nature of the goods and on seller's will. The price for packaging is set according to the inserted clause, namely:

- netto clause, according to which the packaging cost is included in the goods;

- netto clause plus packaging which shows that the value of the packaging is calculated separately;

- brutto per netto clause, meaning that the packaging is calculated to the unit price of the goods.

Nevertheless, the parties may not discuss the issue of packaging.

There is an express regulation in the international practice for the sales of machines and equipment, due to their importance. By the time of the discussing it, there are two situations:

- the prices indicated in the prices lists and catalogues are considered as being for the nude goods;

- the prices in the firm tenders and in the agreements also comprise the packaging or the required protection means for avoiding the deterioration under normal shipment to destination.

- expenses on shipment (art. 32 par. 2 of the Vienna Convention, 1980)

As element of the price, the expenses for the shipment are considered depending on the delivery terms. They divide between the contracting parties by the way of selling to be used, which means:

- in Ex works selling, the shipment is incumbent to the buyer;

- in $F O B$ selling, the seller is responsible with the expenses on the goods delivery to the harbour and on the loading coasts, while the buyer is in charge with the chartering expenses. 
- expenses on the insurance (art. 32 par. 3 of the Vienna Convention, 1980)

Insuring the goods against shipment risks is a non-essential, however common operation. Sometimes, the granting of bank credits for funding a sale is conditioned by the goods insurance.

The expenses on the insurance are an element of the price only in CIF selling. In this clause, the seller has to acquire, at his/her own expense, a maritime transferable insurance policy.

The buyer is in charge with the insurance for the other delivery terms.

- various expenses

Other elements of lower value can also be included in the selling price. They rely on expenses such as taxes, customs duties, banking and trading fees or on acquiring some documents stipulated by the regime of the exports and imports.

The international practice shows that various expenses are paid by each partner, as they are performed on the territory of their country.

\section{B. Payment date}

The payment date is either stipulated by the parties or results from the customs. In the international trade, the payment date is the date of effective delivery of the goods or of reception of the ownership titles. In complex exports, the payment of the price is usually gradual, in two or three stages, with various data, specifically the date of concluding the agreement, of submitting the materials and of reception of the goods (23).

C. Location of the payment (art. 57 of the Vienna convention, 1980)

If the buyer is not bound to pay the price at any other particular place, he must pay it to the seller:

(a) at the seller's place of business; or

(b) if the payment is to be made against the handing over of the goods or of documents, at the place where the handing over takes place.

The seller must bear any increase in the expenses incidental to payment which is caused by a change in his place of business subsequent to the conclusion of the contract.

\section{Liability for the non-performance of the obligation to pay the price}

The non-performance of the buyer's obligation to pay the price may present two aspects

- delay of the payment;

- not paying the price.

If the payment of the price is performed with delay, the seller must ask for penalties and may suspend the execution of the agreement. 
The penalties of delay are stipulated by the parties in the agreement. They are set in percentage, for each day of delay to the agreed deadlines.

Due to buyer's delay, the seller is also entitled to suspend the execution of the agreement. The suspension occurs automatically, no formality being required.

In the circumstance of not paying the price, the seller has the possibility to ask for the execution of the obligation or for the termination of the agreement.

2. Reception of the goods (art. 60 of the Vienna convention, 1980)

Besides the payment of the price, the buyers also have the obligation for reception of the sold goods. He is compelled to perform all required documents for the delivery-reception operation.

The buyer's attributions are quite low. Depending on the delivery nature, it has to comply with the seller's indications.

In case the buyer fails to accomplish the obligation of reception of the goods, the seller must ask for the execution of the agreement or for the resolution of the sale.

\section{References}

[1] Chirilă Nicolae, Convenţia Naţiunilor Unite asupra contractelor de vânzare internaţională de mărfuri Viena 1980, Universul Juridic, București, 2011, p. 6

[2] Iftime Emanuela, Ioan Macovei, Probleme ale Convenţiei Naţiunilor Unite asupra Contractelor de vânzare internaţională de mărfuri prin prisma Statelor nesemnatare, în Analele Universităţii de Vest din Timişoara, Seria Drept, Volumul 2/2012 p. 114

[3] Textul Convenţiei a fost publicat în M. Of. nr. 54 din 19 martie 1991, împreună cu Legea nr. 24/1991 pentru aderarea României la Convenţia Naţiunilor Unite asupra contractelor de vânzare internaţională de mărfuri

[4] Legea nr. 24/1992 a fost în „Monitorul oficial al României”, partea I, nr. 46/1992

[5] D.A. Sitaru, Drept comercial internaţional, Tratat, Volumul II, Ed. Actami, Bucureşti, 1996, p. 233 şi urm.

[6] I. Macovei, Dreptul comerțului international, vol. II, editura C.H BECK, București, 2009

[7] Pavel Palcu, Dreptul comerțului international, Editura Vasile Goldiș, Arad, 2002, pp. $112-113$

[8] Convenţia Naţiunilor Unite asupra contractelor de vânzare internaţională de mărfuri Viena 1980 